\title{
Detection of Viruses in Sweetpotato from Honduras and Guatemala Augmented by Deep-Sequencing of Small-RNAs
}

M. Kashif, S. Pietilä, and K. Artola, Department of Agricultural Sciences, FI-00014 University of Helsinki, Finland; R. A. C. Jones, School of Plant Biology and Institute of Agriculture, Faculty of Natural and Agricultural Sciences, University of Western Australia, Perth, WA 6009, and Department of Agriculture, Locked Bag No. 4, Bentley Delivery Centre, Perth, WA 6983, Australia; A. K. Tugume, Department of Agricultural Sciences, University of Helsinki, and Department of Biological Sciences, College of Natural Sciences, Makerere University, Kampala, Uganda; V. Mäkinen, Department of Computer Science, University of Helsinki, Finland; and J. P. T. Valkonen, Department of Agricultural Sciences, University of Helsinki

\begin{abstract}
Kashif, M., Pietilä, S., Artola, K., Jones, R. A. C., Tugume, A. K., Mäkinen, V., and Valkonen, J. P. T. 2012. Detection of viruses in sweetpotato from Honduras and Guatemala augmented by deep-sequencing of small-RNAs. Plant Dis. 96:1430-1437.

Sweetpotato (Ipomoea batatas) plants become infected with over 30 RNA or DNA viruses in different parts of the world but little is known about viruses infecting sweetpotato crops in Central America, the center of sweetpotato domestication. Small-RNA deep-sequencing (SRDS) analysis was used to detect viruses in sweetpotato in Honduras and Guatemala, which detected Sweet potato feathery mottle virus strain RC and Sweet potato virus C (Potyvirus spp.), Sweet potato chlorotic stunt virus strain WA (SPCSV-WA; Crinivirus sp.), Sweet potato leaf curl Georgia virus (Begomovirus sp.), and Sweet potato pakakuy virus strain B (synonym: Sweet potato badnavirus B). Results

amplicons. Four viruses were detected in a sweetpotato sample from the Galapagos Islands. Serological assays available to two of the five viruses gave results consistent with those obtained by SRDS, and were negative for six additional sweetpotato viruses tested. Plants coinfected with SPCSV-WA and one to two other viruses displayed severe foliar symptoms of epinasty and leaf malformation, purpling, vein banding, or chlorosis. The results suggest that SRDS is suitable for use as a universal, robust, and reliable method for detection of plant viruses, and especially useful for determining virus infections in crops infected with a wide range of unrelated viruses.
\end{abstract} were confirmed by polymerase chain reaction and sequencing of the
Sweetpotato (Ipomoea batatas Lam.; family Convolvulaceae) is the only species producing edible tuberous roots among the approximately 500 species belonging to the genus Ipomoea (42). Archeological as well as molecular evolutionary studies indicate that sweetpotato was first domesticated in the Americas in the region between the Yucatan Peninsula of Mexico to the north and the Orinoco river in Venezuela to the south. This region includes the Central American countries of Guatemala and Honduras. The Peru-Ecuador region of South America constitutes an important secondary center of sweetpotato domestication $(4,46)$. The crop has been distributed widely and is now the third most important root crop globally after potato and cassava (23). Sweetpotato plants are grown in all tropical or subtropical regions of the developed and developing world. In developing countries with tropical climates, it is often grown as a food crop by subsistence farmers.

Production of sweetpotato is hampered by biotic constraints, especially virus diseases. Sweet potato feathery mottle virus (SPFMV; genus Potyvirus, family Potyviridae) has the widest known distribution of all sweetpotato viruses, being detected in all sweetpotato production regions of the world surveyed thus far $(14,25,32,34,35,37)$. Previously, SPFMV was considered to consist of four strains (C, EA, O, and RC; 17); however, strain $\mathrm{C}$ is now classified as a distinct Potyvirus sp. (Sweet potato virus $C$ [SPVC]; 35,39). Co-infection with SPFMV and Sweet potato chlorotic stunt virus (SPCSV; genus Crinivirus, family Closteroviridae) induces a

Corresponding author: J. Valkonen, E-mail: jari.valkonen@ helsinki.fi

M. Kashif, S. Pietilä, and K. Artola contributed equally to this work.

Accepted for publication 25 April 2012.

http://dx.doi.org/10.1094/PDIS-03-12-0268-RE

(c) 2012 The American Phytopathological Society synergistic disease called "sweet potato virus disease" (SPVD) in sweetpotato plants. It causes the most severe yield losses induced by any pathogen in the crop $(7,11,15)$. SPCSV also synergizes many other sweetpotato viruses belonging to a wide range of taxonomic groups (38). It consists of strain EA that occurs in East Africa and strain WA that is widely distributed, occurring in western Africa and South and North America (6,35).

The number of viruses known to infect sweetpotato has doubled in just a few years and now exceeds 30 RNA or DNA viruses (5). The current rapid improvement in virus detection procedures includes development of molecular methods which detect different members of large groups of viruses or do not require any prior information about the viruses present. Rolling circle amplification can be used to detect viruses in the genera Begomovirus and Mastrevirus (family Geminiviridae) which contain circular, singlestranded DNA genomes (12,30). However, more universal detection is offered by analysis of virus-derived small interfering RNAs (siRNAs) that accumulate in infected plant tissues due to the antiviral defense mechanism based on RNA silencing (22). This approach, based on small-RNA deep-sequencing (SRDS), was first applied to detect five different viruses in a single sweetpotato 'Huachano' plant inoculated with SPCSV-EA and SPFMV (18). Analysis of its siRNA revealed the presence of three additional previously unknown viruses. These included two related Badnavirus spp. (18), later designated as strains A and B of Sweet potato pakakuy virus (SPPV, genus Badnavirus; family Caulimoviridae) (5), and Sweet potato symptomless virus 1 (SPSMV-1, genus Mastrevirus; family Geminivirdae) $(5,18)$. Thus, SRDS is a novel method that detects both RNA and DNA viruses. It was applied subsequently to virus surveys (e.g., in grapevine [29,47] and wild cocksfoot grass [Dactylis glomerata; 28]).

The principal aim of this study was to use SRDS to determine which viruses occur in sweetpotato grown in Honduras and Guatemala, both of which are within the main center of domestication of this crop, and in the Galapagos Islands (Ecuador), within the secondary center of domestication. 


\section{Materials and Methods}

Plant material. Tuberous roots of sweetpotato were purchased from local markets in Copan, Honduras (HN) and Guatemala City, Guatemala (GT) in February 2008. The names of the cultivars are unknown, the sellers only referring to them by skin and flesh color. From Copan, numbers HN1 to HN3 and HN5 refer to four tuberous roots of identical appearance (large-sized, elongated shape, purple skin, and cream flesh) from the same market stall. In Guatemala City, tuberous roots A1 and A3 (miniature-sized, elongate shape, red skin, and cream flesh) were purchased from a different stall in the same market than tuberous roots B1 to B3 (miniaturesized, oval shape, purple skin, and cream flesh). Tuberous roots $\mathrm{C} 1$ and C2 (small-sized, oval shape, purple skin, and cream flesh) were purchased from a supermarket. HN1 to HN3 and HN5 were from a crop in the San Pedro Sula region of Honduras and B1 to B3 from one in the Antigua region of Guatemala; however, where the Guatemalan crops that produced the other tuberous roots were grown is unknown. In addition, tuberous roots of sweetpotato were purchased from a market stall in San Cristobal, Galapagos Islands, Ecuador, in February 2010. The seller knew them by the name 'Moradita Dulce' ("purple sweet"). The cultivar had purple skin and white flesh. These and many additional tuberous roots were sent to the University of Helsinki, Finland, by air transport but only the aforementioned tuberous roots from Guatemala and Honduras and a single tuberous root (GLP5) from the Galapagos Islands grew after planting in soil. The reason may be that tuberous roots of sweetpotato do not store well without cooling, which was not available in market stalls from which tuberous roots were purchased. In our previous studies, long-distance shipment of sweetpotato vine cuttings was successful at $100 \%$ survival rate (32). In Helsinki, the plants were grown under controlled conditions (25 to $30^{\circ} \mathrm{C}$, relative humidity $60 \%, 13$-h photoperiod, light intensity of $240 \mathrm{~W} / \mathrm{m}^{2}$ ) in isolation as stipulated by the import permit from the Finnish Food Safety Authority (Evira). These plants were propagated by rooting stem cuttings.

Virus inoculation. Seed of the semi-universal virus indicator species I. setosa Ker Gwal. were grown in autoclaved greenhouse compost until 2 to 3 weeks old. A scion from each Central American sweetpotato plant was side grafted to a plant of I. setosa, and a top scion of I. setosa was top grafted to each sweetpotato plant. After graft inoculation, the foliage of sweetpotato plants and I. setosa was observed for viral disease symptoms for up to 2 months.

Serological testing of viruses. Serological testing for SPFMV, Sweet potato latent virus (SPLV), Sweet potato mild speckling virus (SPMSV), and Sweet potato virus $G$ (SPVG), all belonging to genus Potyvirus (family Potyviridae); Sweet potato mild mottle virus (SPMMV, genus Ipomovirus; Potyviridae); Sweet potato collusive virus (SPCoV; synonym, Sweet potato caulimo-like virus) (genus Cavemovirus; family Caulimoviridae); and the C-6 virus (family Flexiviridae) was conducted with antibodies provided by the International Potato Center (CIP) (Lima, Peru) using their recommended dilutions. Nitrocellulose membrane enzyme-linked immunosorbent assay (NCM-ELISA) was carried out according to the protocol of Gibb and Padovan (9). Signals were developed using 5-bromo-4-chloro-3-indolyl phosphate/nitro blue tetrazolium chloride ( $\mathrm{pH}$ 9.5) as a substrate (Sigma-Aldrich). Results were evaluated visually.

To detect SPCSV, triple-antibody sandwich (TAS)-ELISA was done as described (11) using anti-SPCSV polyclonal antibodies (diluted 1:1000) and either anti-SPCSV-EA monoclonal antibody (MAb) mix 1 or anti-SPCSV-WA MAb mix 2 (diluted 1:100), kindly provided by H. J. Vetten, Braunschweig, Germany. The third antibodies used were anti-mouse alkaline phosphatase-conjugated goat antibodies purchased from Sigma-Aldrich (diluted 1:1000). Absorbances were recorded at an absorbance of $405 \mathrm{~nm}$ with a Benchmark Microtitre Plate Reader (Bio-Rad Laboratories).

Isolation of RNA and DNA. Total RNA was isolated from 100 to $200 \mathrm{mg}$ of fresh sweetpotato leaves using Trizol (Invitrogen) according to the manufacturer's instructions. RNA was dissolved in $50 \mu \mathrm{l}$ of sterile Milli-Q water (MQW) (Sigma-Aldrich). The quantity and quality of the RNA were measured using a spectrophotometer and by agarose gel electrophoresis. DNA was isolated from sweetpotato leaves as described (2).

Small-RNA deep-sequencing. Equal amounts of total RNA from the 11 sweetpotato plants were pooled, and $10 \mu \mathrm{g}$ from the pool of RNA was sent to a deep-sequencing service (Fasteris SA) for processing. In brief, the procedure for small-RNA sequencing included separation of RNA by electrophoresis in an acrylamide gel, isolation of small RNA ( $<30$ nucleotides [nt]) from the gel, and ligation with a single-stranded $3^{\prime}$ adapter and a bar-coded $5^{\prime}$ adapter. This was followed by reverse-transcription and amplification by polymerase chain reaction (PCR) to generate a DNA colony template library. This library was then purified and diluted to a concentration of $10 \mathrm{nM}$. Illumina Genome Analyzer platform technology was applied for high-throughput DNA sequencing.

Detection of DNA viruses by PCR. Badnavirus spp. (SPPV strains A and B, previously known as Sweet potato badnavirus A and $\mathrm{B}$, respectively; 5,18,24), the Mastrevirus SPSMV-1, and $\mathrm{Be}$ gomovirus spp. were detected by PCR. The reaction mix $(25 \mu \mathrm{l})$ for all these viruses contained $0.5 \mu \mathrm{l}$ of $50 \mathrm{mM} \mathrm{MgCl}, 1 \mu \mathrm{l}$ of $10 \mathrm{mM}$ dNTPs, $1 \mu \mathrm{l}$ of the forward $(10 \mu \mathrm{M})$ and reverse $(10 \mu \mathrm{M})$ primer, $0.25 \mu \mathrm{l}(0.5 \mathrm{U})$ of Dynazyme II DNA Polymerase (Finnzymes), 2.5 $\mu \mathrm{l}$ of $10 \times$ PCR buffer, $0.5 \mu \mathrm{l}$ of DNA, and $18.25 \mu \mathrm{l}$ of MQW to make the final volume of $25 \mu \mathrm{l}$.

The forward $(\mathrm{F})$ and reverse $(\mathrm{R})$ primers for SPPV-A (rt-badA-F, 5'-CAGGTGTCACAACAAGCTCC-3'; rt-badA-R, 5'-AGTCGG GGGTCCACTTATCT-3') and SPVV-B (rt-badB-F, 5'-TCGGCA GTAACAGACTACTTGG-3'， rt-badB-R， 5'-TCTGCTTATCAT CTCCGTTGG-3') were designed according to open reading frame (ORF)3a sequences (FJ560943 and FJ560944) (18) to amplify a fragment of 167 and $147 \mathrm{nt}$, respectively (I. Weinheimer, unpublished). The primers for SPSMV-1 (rt-mas1-F2, 5'-AGGCTT TCTATGCGAGTTGTGG-3'; rt-mas1-R2, 5'-CACGTATTTGGG AAGTTCTGG-3') were designed to amplify a 130-nt fragment of the coat protein $(\mathrm{CP})$ gene (I. Weinheimer, unpublished). The PCR program was $94^{\circ} \mathrm{C}$ for $150 \mathrm{~s} ; 30$ cycles of $94^{\circ} \mathrm{C}$ for $30 \mathrm{~s}, 59^{\circ} \mathrm{C}$ for $30 \mathrm{~s}$, and $72^{\circ} \mathrm{C}$ for $20 \mathrm{~s}$; followed by final extension at $72^{\circ} \mathrm{C}$ for 8 min. Begomovirus spp. were tested with universal primers AV494 (5'-GCCYATRTAYAGRAAGCCMAG-3') and AC1048 (5'-GGR TTDGARGCATGHGTACATG-3') amplifying the CP core region (576 nt) (43). The PCR program was $95^{\circ} \mathrm{C}$ for $3 \mathrm{~min}$; followed by 30 cycles of $95^{\circ} \mathrm{C}$ for $30 \mathrm{~s}, 58^{\circ} \mathrm{C}$ for $30 \mathrm{~s}$, and $72^{\circ} \mathrm{C}$ for $40 \mathrm{~s}$; followed by final extension at $72^{\circ} \mathrm{C}$ for $8 \mathrm{~min}$.

In addition, Sweet potato leaf curl virus (SPLCV, genus Begomovirus) was tested for with primers SPLCV-F (5'-GCCTGA TTACATAAACTAAATTGA-3') and SPLCV-R (5'-TTAAGAACG CAATATTCTGTG-3') designed based on the sequences recovered in this study by small-RNA analysis. They were designed to amplify a region containing a partial AC3 gene, the entire AC2 gene, and a partial $\mathrm{AC} 1$ gene. The PCR program was $94^{\circ} \mathrm{C}$ for $150 \mathrm{~s}$; followed by 30 cycles of $94^{\circ} \mathrm{C}$ for $30 \mathrm{~s}, 58^{\circ} \mathrm{C}$ for $30 \mathrm{~s}$, and $72^{\circ} \mathrm{C}$ for $30 \mathrm{~s}$; followed by final extension at $72^{\circ} \mathrm{C}$ for $8 \mathrm{~min}$.

Virus detection by reverse-transcription PCR. Total RNA from sweetpotato leaves was reverse transcribed in a reaction mixture $(25 \mu \mathrm{l})$ containing $100 \mathrm{ng}$ of random hexamer primers, 0.5 $\mathrm{mM}$ dNTPs, $20 \mathrm{U}$ of RNasin, and $400 \mathrm{U}$ of Moloney murine leukemia virus reverse transcriptase (Promega Corp.) at $37^{\circ} \mathrm{C}$ for $1 \mathrm{~h}$ following the manufacturer's instructions. The cDNA was used for detection of SPCSV, SPFMV, and SPVC by PCR. For SPCSV, a fragment (446 nt) of the $H s p 70 h$ gene located on RNA2 was amplified with primers CL43L (5'-GCAGCAGAAGGCTCGTTTAT-3') and CL43U (5'-ATCGGCGTATGTTGGTGGTA-3') as described (13). Furthermore, a region of RNA1 containing the RNase 3 and $P 7$ genes was amplified with the forward primer WAF1 ( $5^{\prime}-$ GAAAATTCTGTCCCATATTTC-3') and reverse primer WAR1 (5'-CTCTAGGATACAAACATTAAT- $\left.3^{\prime}\right)$ designed to detect SPCSV-WA strain isolate Is (EU124491) (8) using the DyNAzyme II DNA Polymerase (Finnzymes). For SPFMV and SPVC, the CPencoding region was amplified with the Potyvirus-specific (de- 
generate) forward primer PVD-2 (5'-GGBAAYAAYAGYGGD CARCC-3') against the NIb region (10) and the reverse primer 10820R (5'-GGCTCGATCACGAACCAA-3') complementary to the $3^{\prime}$ end of the nontranslated region, as described (10), using the high-fidelity Phusion DNA Polymerase (Finnzymes).

Restrictotype analysis. SPFMV and SPVC amplicons were distinguished by restriction analysis (10). The PCR amplicons were purified from the gel using an E.Z.N.A.T Gel Extraction Kit
(Omega Bio-Tek) and subjected to restriction with endonucleases HindIII and $P v u I I$ at $37^{\circ} \mathrm{C}$ overnight. The restriction pattern was observed following fragment separation by gel electrophoresis in a $1 \%$ agarose gel.

DNA sequencing. PCR products were purified as described above and DNA concentration was measured using a spectrophotometer. In most cases, PCR products were sequenced directly without cloning; however, PCR products of SPFMV, SPVC, and

Table 1. Virus isolates from this study and sequences retrieved from the databank for comparison

\begin{tabular}{|c|c|c|c|c|}
\hline Virus $^{\mathrm{a}}$ & Geographic origin & $\begin{array}{l}\text { Genomic region } \\
\text { analyzed }^{b}\end{array}$ & $\begin{array}{c}\text { Database } \\
\text { accession number }\end{array}$ & Reference \\
\hline \multicolumn{5}{|l|}{ SPFMV } \\
\hline HN:5RC:08 & Copan, Honduras & $\mathrm{CP}$ & JF699625 & This study \\
\hline Arua10a & Arua, Uganda & $\mathrm{CP}$ & AY459595 & E. M. Ateka 2003, unpublished \\
\hline Aus2 & Perth, Australia & $\mathrm{CP}$ & AJ781775 & 35 \\
\hline Aus5 & Perth, Australia & $\mathrm{CP}$ & AJ781776 & 35 \\
\hline Aus6 & Perth, Australia & $\mathrm{CP}$ & AJ781777 & 35 \\
\hline Bag & Bagamoyo, Tanzania & $\mathrm{CP}$ & AJ781780 & 35 \\
\hline Bkb1 & Bukoba, Tanzania & $\mathrm{CP}$ & AJ781781 & 35 \\
\hline Bny & Bushenyi, Uganda & $\mathrm{CP}$ & AJ539130 & 27 \\
\hline Fio & Cañete, Peru & $\mathrm{CP}$ & EU021065 & 37 \\
\hline Kab1 & Kabarore, Uganda & $\mathrm{CP}$ & AJ010698 & 35 \\
\hline Ken115-1s & Kenya & $\mathrm{CP}$ & AY523540 & E. M. Ateka 2003, unpublished \\
\hline KmtMil & Cañete, Peru & $\mathrm{CP}$ & EU021066 & 37 \\
\hline M2-41 & Cañete, Peru & $\mathrm{CP}$ & EU021064 & 37 \\
\hline MBL & Mbale, Uganda & $\mathrm{CP}$ & AJ010701 & 17 \\
\hline Nak & Nakasongola, Uganda & $\mathrm{CP}$ & AJ781790 & 35 \\
\hline SPFMV-K1 & Korea & $\mathrm{CP}$ & AF015540 & 33 \\
\hline $\mathrm{TZ4}$ & Tanzania & $\mathrm{CP}$ & AY459598 & E. M. Ateka 2003, unpublished \\
\hline \multicolumn{5}{|l|}{ SPVC } \\
\hline $\mathrm{HN}: 2 \mathrm{C}: 08$ & Copan, Honduras & $\mathrm{CP}$ & JF699626 & This study \\
\hline HN:5C:08 & Copan, Honduras & $\mathrm{CP}$ & JF699627 & This study \\
\hline Aus $4 \mathrm{c}$ & Perth, Australia & $\mathrm{CP}$ & AJ781778 & 35 \\
\hline Aus5c & Perth, Australia & $\mathrm{CP}$ & AJ781779 & 35 \\
\hline $\mathrm{C} 21$ & Cañete, Peru & $\mathrm{CP}$ & EU021061 & 37 \\
\hline $\mathrm{Ch} 4$ & Chimbote, Peru & $\mathrm{CP}$ & EU021062 & 37 \\
\hline Ita1 & Latium, Italy & $\mathrm{CP}$ & AM076411 & 31 \\
\hline Pink-2c & Perth, Australia & $\mathrm{CP}$ & AM050893 & 34 \\
\hline Sor & Soroti, Uganda & $\mathrm{CP}$ & AJ539129 & 27 \\
\hline Spain1C & Spain & $\mathrm{CP}$ & AY518937 & E. M. Ateka 2004, unpublished \\
\hline \multicolumn{5}{|c|}{ SPCSV $(H s p 70 h)$} \\
\hline GT:A1:08 & Guatemala City, Guatemala & HSP70h & JF699629 & This study \\
\hline GT:A3:08c & Guatemala City, Guatemala & HSP70h & JF699631 & This study \\
\hline GT:B3:08 & Guatemala City, Guatemala & HSP70h & JF699628 & This study \\
\hline GT:C1:08 & Guatemala City, Guatemala & HSP70h & JF699630 & This study \\
\hline HN1 & Copan, Honduras & HSP70h & GU127600 & This study \\
\hline $115-6 \mathrm{~S}$ & Kenya & HSP70h & DQ864367 & 3 \\
\hline $15-3 \mathrm{~S}$ & Kenya & HSP70h & DQ864365 & 3 \\
\hline $13-1 \mathrm{~S}$ & Kenya & HSP70h & DQ864364 & 3 \\
\hline $84-5 S$ & Kenya & HSP70h & DQ864369 & 3 \\
\hline B4 & Spain & HSP70h & EF667069 & 40 \\
\hline Bag & Bagamoyo, Tanzania & HSP70h & AJ783445 & 35 \\
\hline Egypt1 & Delta area, Egypt & HSP70h & AJ515381 & 13 \\
\hline HSP70-USA & United States & HSP70h & AF260321 & J. Sim et al., unpublished \\
\hline Iganga1 & Uganda & HSP70h & DQ864358 & 3 \\
\hline Is & Israel & HSP70h & EU124487 & 8 \\
\hline Madagascar & Madagascar & HSP70h & DQ864334 & N. Fenby 2002, unpublished \\
\hline Mukono5 & Uganda & HSP70h & DQ864363 & 3 \\
\hline $\mathrm{m} 2-47$ & Peru & HSP70h & EU124488 & 8 \\
\hline Nigeria1 & Nigeria & HSP70h & AJ278652 & N. Fenby 2002, unpublished \\
\hline Nigeria2 & Nigeria & HSP70h & AJ278653 & N. Fenby 2002, unpublished \\
\hline SIEA-11 & Uganda & HSP70h & AJ010754 & 1 \\
\hline Tar2 & Tanzania & HSP70h & AJ783448 & 35 \\
\hline TZ394 & Tanzania & HSP70h & DQ864373 & 3 \\
\hline Zambia 1 & Zambia & HSP70h & DQ864374 & 3 \\
\hline \multicolumn{5}{|l|}{ SPCSV (RNA1) } \\
\hline GT:A1:08 & Guatemala City, Guatemala & RNA1 & GU127601 & This study \\
\hline HN1 & Guatemala City, Guatemala & RNA1 & GU127600 & This study \\
\hline Is & Israel & RNA1 & EU124491 & 8 \\
\hline \multicolumn{5}{|l|}{ SPLCGV } \\
\hline GT-A1 & Guatemala City, Guatemala & DNA-A & FN995425 & This study \\
\hline
\end{tabular}

${ }^{\text {a }}$ SPFMV = Sweet potato feathery mottle virus, $\mathrm{SPVC}=$ Sweet potato virus $C, \mathrm{SPCSV}=$ Sweet potato chlorotic stunt virus, and SPLCGV $=$ Sweet potato leaf curl Georgia virus.

${ }^{\mathrm{b}} \mathrm{CP}=$ coat protein.

${ }^{c}$ Sequence identical to GT:B1:08 and GT:B2:08. 
SPCSV RNA1 were cloned for sequencing. PCR products that contained both SPFMV and SPVC were cloned in Escherichia coli DH5a cells using the pGEM-T Easy Vector System (Promega Corp.) according to the manufacturer's instructions. Colonies were selected by PCR using primers PVD-2 and 10820R. The fragments of expected size $(1.8 \mathrm{~kb})$ were purified from the gel and restrictotyped by treatment with $\mathrm{HindIII}$ and $P v u \mathrm{II}$ at $37^{\circ} \mathrm{C}$ overnight, as described above. Subsequently, colonies containing clones of either SPFMV or SPVC were selected and grown, the plasmids purified, and the inserts sequenced at the Haartman Institute DNA sequenc- ing unit (University of Helsinki, Finland). The PCR products amplified from SPCSV RNA1 with Phusion were poly(A)-tailed using DyNAzyme II DNA polymerase according to the manufacturer's instructions to facilitate cloning with the pGEM-T system, as described above. Two or more amplicons obtained in independent PCRs were sequenced for each isolate. New nucleotide sequences from this study were deposited in the National Center for Biotechnology Information (NCBI) sequence database (Table 1).

Sequence analysis. Small-RNA reads were analyzed essentially as described by Kreuze et al. (18). Subsets based on the read length
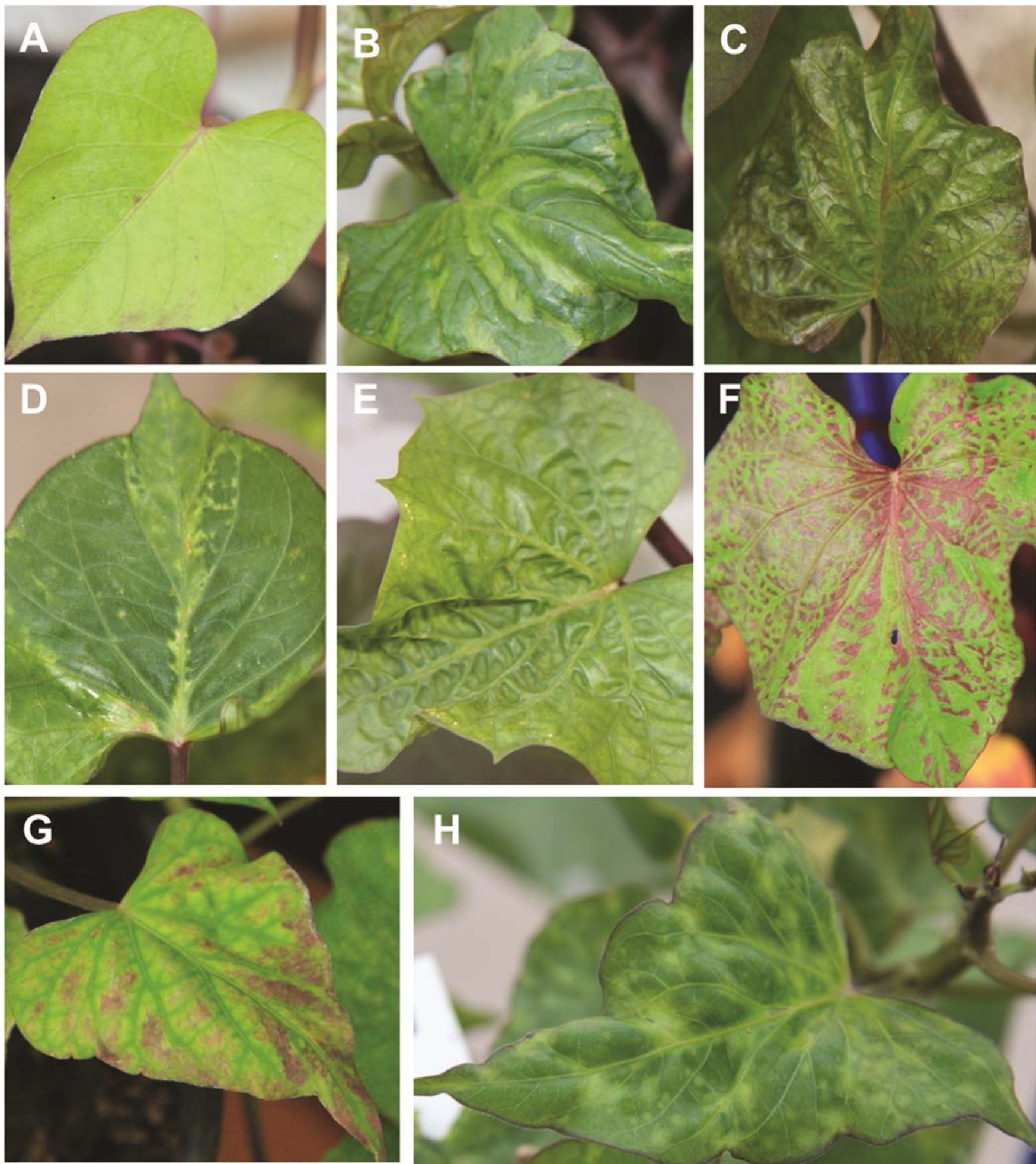

Fig. 1. Symptoms in sweetpotato plants grown from tuberous roots originating from Guatemala (GT) and Honduras (HN). A, GT-C2, no symptoms and no virus detected; B, GT-A1, vein banding, epinasty, leaf malformation; C, GT-A3, epinasty, leafcurl, purpling; D, GT-B1, vein clearing, mottle, leaf deformation; E, GT-B2, chlorosis, vein clearing, epinasty, leaf malformation; F, GT-C1, purpling of leaves; G, GT-B3, chlorosis, purpling; H, HN1, chlorotic mottle, vein clearing, epinasty, leaf malformation. 
$(21,22,23$, or $24 \mathrm{nt})$ were provided as an input to the Velvet assembler developed for assembly of contiguous sequences (contigs) from overlapping short sequences (45). Various lengths of overlap ( $k$-mer values), including 15 and 17 , were tested to modulate specificity and subjected to the error-removing correction functions of Velvet (45). The contigs assembled were used as queries in searches carried out in the NCBI database by BLAST. The viral sequences retrieved were used as references for alignment of smallRNA reads with MAQ (MAQ User's Manual, release 0.5.0) and to build assemblies by mapping the small-RNA reads to reference virus sequences (21). Alignments of sequences determined in this study and those retrieved from the NCBI sequence database (Table 1) were done using ClustalX 2.0. Phylogenetic neighbor-joining trees were constructed using the Kimura two-parameter method based on Clustal-X alignments using MEGA version 4 (36).

\section{Results}

Symptoms in sweetpotato and $I$. setosa plants. In all, 10 of the 12 sweetpotato plants grown from the tuberous root samples displayed virus-like symptoms such as leaf epinasty, vein clearing or vein banding, purpling of leaves, feathery mottling, chlorotic mottle, and leaf malformation (Fig. 1; Table 2). Growth of the plants displaying leaf epinasty and malformation was reduced significantly. When the plants were cut back 3 months after planting the tuberous roots, symptoms similar to those that developed previously in the same plants were reproduced in the new shoots. The vines and shoots of $I$. setosa grafted with or to sweetpotato plants developed foliar symptoms which consisted of chlorotic or necrotic spots, leaf curling, and wilting; however, grafting with the symptomless plant GT-C2 resulted in no symptoms in I. setosa (Table 2). Plants GLP5, HN2, HN3, and HN5 were not tested by grafting with I. setosa.

Viruses detected by small-RNA deep-sequencing. SRDS on the pooled RNA ( $10 \mu \mathrm{g}$ ) from 11 sweetpotato plants from Guatemala and Honduras resulted in 4,155,175 reads (size range, 10 to $27 \mathrm{nt}$ ) and a total of 132,965,600 bases. The majority of reads were $22 \mathrm{nt}$ long. Assembling the 21- to 24-nt-long reads with Velvet resulted in contigs of varying size up to $824 \mathrm{nt}$ long. The contigs were mapped against the NCBI nucleotide database using the BLAST tool, which suggested significant similarity with six viruses: SPFMV, SPVC, SPCSV-WA, SPPV-A, SPPV-B, and Sweet potato leaf curl Georgia virus (SPLCGV, genus Begomovirus). Sequences of these six viruses were retrieved from the NCBI nucleotide database and used as an input for the MAQ tool, which used the viral reference sequences to create an assembly from the original small-RNA sequences by mapping the reads against the reference sequence. Coverage of the DNA-A sequence of SPLCGV (AF326775) was very high (98\%). Similarly, coverage of the genome sequence of SPPV-B (FJ560944) was high (81\%) but less $(50 \%)$ with the previously characterized genomic regions of SPPV-A (FJ560943). Coverage of the partial genome sequence of

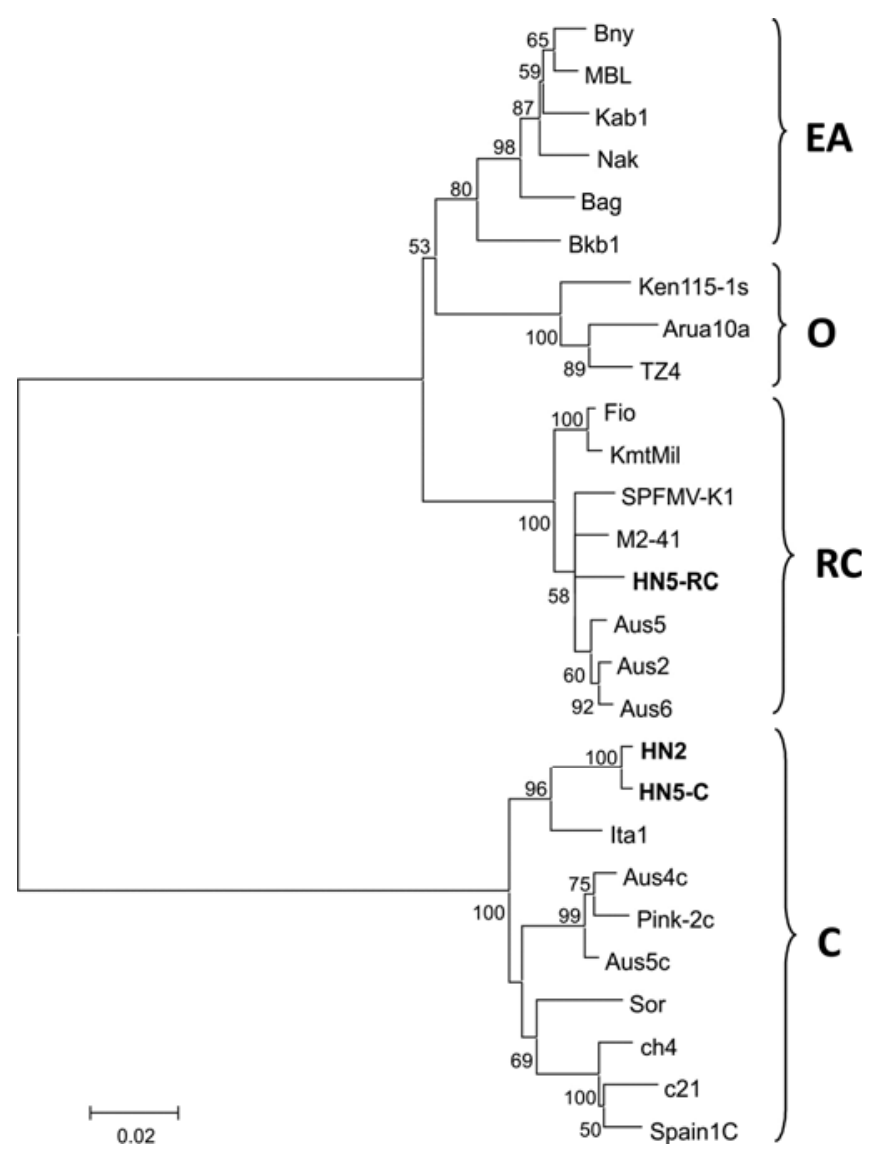

Fig. 2. Phylogenetic analysis of the Sweet potato feathery mottle virus (SPFMV) and Sweet potato virus C (SPVC) coat-protein-encoding sequences (945 nucleotides). Clusters containing isolates belonging to SPVC (C) or SPFMV strains $E A, O$, and $R C$ are shown. Scale bar shows Kimura units (16). Bootstrap values are for of 1,000 replicates.

Table 2. Symptoms observed and viruses detected in sweetpotato plants grown from tuberous roots from Central America and in graft-inoculated plants of Ipomoea setosa

\begin{tabular}{|c|c|c|c|c|c|c|c|c|c|}
\hline \multirow[b]{2}{*}{ Plant $^{c}$} & \multicolumn{2}{|c|}{ Symptoms ${ }^{a}$} & \multicolumn{7}{|c|}{ Viruses detected $^{b}$} \\
\hline & Sweetpotato & I. setosa & SPFMV & SPVC & SPCSV-WA & SPPV-A & SPPV-B & SPLCGV & SPSMV-1 \\
\hline GLP5 & Mfm & $\mathrm{Nt}$ & + & $\mathrm{Nt}$ & - & + & + & - & + \\
\hline GT-A1 & Ep, Lmal, VB & $\mathrm{CS}, \mathrm{NS}, \mathrm{W}$ & - & - & + & - & - & + & - \\
\hline GT-A3 & Ep, Lcr, Prp & $\mathrm{CS}, \mathrm{NS}, \mathrm{W}$ & - & - & + & - & - & + & - \\
\hline GT-B1 & Mo, VC, Lmal & CS, Lcr, NS & - & - & + & - & - & - & - \\
\hline GT-B2 & Chl, VC, Ep, Lmal & $\mathrm{CS}$ & - & - & + & - & - & - & - \\
\hline GT-B3 & Chl, Prp & $\mathrm{CS}, \mathrm{NS}, \mathrm{W}$ & - & - & + & - & - & - & - \\
\hline GT-C1 & Prp & CS, Lcr & - & - & + & - & - & + & - \\
\hline GT-C2 & $\mathrm{ns}$ & $\mathrm{ns}$ & - & - & - & - & - & - & - \\
\hline HN1 & CS, Lmal, Mo, VC & $\mathrm{CS}, \mathrm{Lcr}$ & - & - & + & - & + & - & - \\
\hline HN2 & $\mathrm{CS}$ & $\mathrm{Nt}$ & - & + & - & - & + & - & - \\
\hline HN3 & $\mathrm{ns}$ & $\mathrm{Nt}$ & - & - & - & - & + & - & - \\
\hline HN5 & $\mathrm{CS}$ & $\mathrm{Nt}$ & + & + & - & - & + & - & - \\
\hline
\end{tabular}

${ }^{a}$ Chl, chlorosis; CS, chlorotic leaf spots; Ep, epinasty; Lcr, leaf curling; Lmal, leaf malformation; Mfm, mild feathery mottling; Mo, leaf mottle; NS, necrotic leaf spots; Prp, leaf purpling; VC, vein clearing; VB, green vein banding; W, wilting of young leaves; ns, no symptoms; Nt, not tested.

${ }^{\mathrm{b}}$ Viruses detected by reverse-transcription polymerase chain reaction in the sweetpotato plants. SPFMV $=$ Sweet potato feathery mottle virus, SPVC $=$ Sweet potato virus $C$, SPCSV-WA = Sweet potato chlorotic stunt virus strain WA, SPPV-A and $-\mathrm{B}=$ Sweet potato pakakuy virus strains A and $\mathrm{B}$, and SPLCGV = Sweet potato leaf curl Georgia virus; +, virus-positive and -, virus-negative. Amplification products were sequenced to verify the viruses found.

${ }^{c}$ Sweetpotato plants were grown in an insect-proof greenhouse from the original tuberous roots obtained from the Galapagos Islands (GLP), Honduras (HN), and Guatemala (GT). Plants were cut down twice during the period of 10 months of observation made. Scions of $I$. setosa were graft inoculated onto sweetpotato plants. Symptoms were observed in the young and full-grown leaves on actively growing vines and scions. 
SPCSV-WA (EU124491), including the RNase 3 and $P 7$ genes, was $84 \%$. The genome of SPFMV-RC (D86371) was $47 \%$ covered, whereas the 3'-proximal genomic region of SPVC of a previously described virus isolate (AY523543) corresponding to the genomic region amplified with the universal Potyvirus primers also in this study was $31 \%$ covered.

Viruses detected in sweetpotato plants by ELISA and PCR. When samples from the 12 sweetpotato plants were tested for viruses by NCM-ELISA, SPFMV was detected in plants GLP5 and HN5 but tests for SPLV, SPMSV, SPVG, SPMMV, SPCoV, and C6 were negative. With TAS-ELISA, plant HN1 and all but one plant (GT-C2) from Guatemala were positive when tested with antiSPCSV-WA MAb Mix 2. However, no plant was positive when tested with anti-SPCSV-EA MAb Mix 1.

Because the polyclonal antibodies to SPFMV provided by CIP do not recognize SPVC (27), all plants except GLP5 were tested by reverse-transcription (RT)-PCR using universal Potyvirus primers PVD-2 and 10820R. They generated amplicons from plant HN5, which was sero-positive for SPFMV, and also from sero-negative plant HN2 (Table 2). Restrictotype analysis of the PCR amplicons indicated that plant HN5 was co-infected with SPFMV and SPVC, whereas plant HN2 was infected only with SPVC. These findings were confirmed by cloning and sequencing the PCR products (Table 1) and comparing these with sequences of selected isolates of SPFMV and SPVC by phylogenetic analysis (Fig. 2).

RT-PCR tests using primers CL43L and CL43U, which amplify the $H s p 70 h$ gene located on RNA2 of SPCSV and detect both EA and WA strains $(1,3)$, indicated that plant $\mathrm{HN} 1$ and all but one plant (GT-C2) from Guatemala were PCR-positive (Table 2). Sequencing the amplicons showed that the amplified Hsp70h gene region was identical (plants GT-A3, GT-B1, and GT-B2) or nearly identical among the virus isolates. Phylogenetic analysis showed that all SPCSV isolates belonged to strain WA (Fig. 3), consistent with the TAS-ELISA findings. The 3 '-proximal part of SPCSV RNA1 was amplified from plants HN1 and GT-A1 using RT-PCR and sequenced (Table 1), which revealed that the ORF for $\mathrm{p} 22$ was missing from both virus isolates.

Small-RNA analysis indicated that one or several plants contained SPLCGV. Primers were designed according to the DNA-A sequence recovered by MAQ analysis and the plants tested by PCR. This resulted in amplicons of the expected size from plants GT-A1, GT-A3, and GT-C1 (Table 2). Amplicons from plant GTA1 were sequenced and found to contain the partial $A C 3$, entire $A C 2$, and partial $A C 1$ genes, as expected. The sequence was depos-

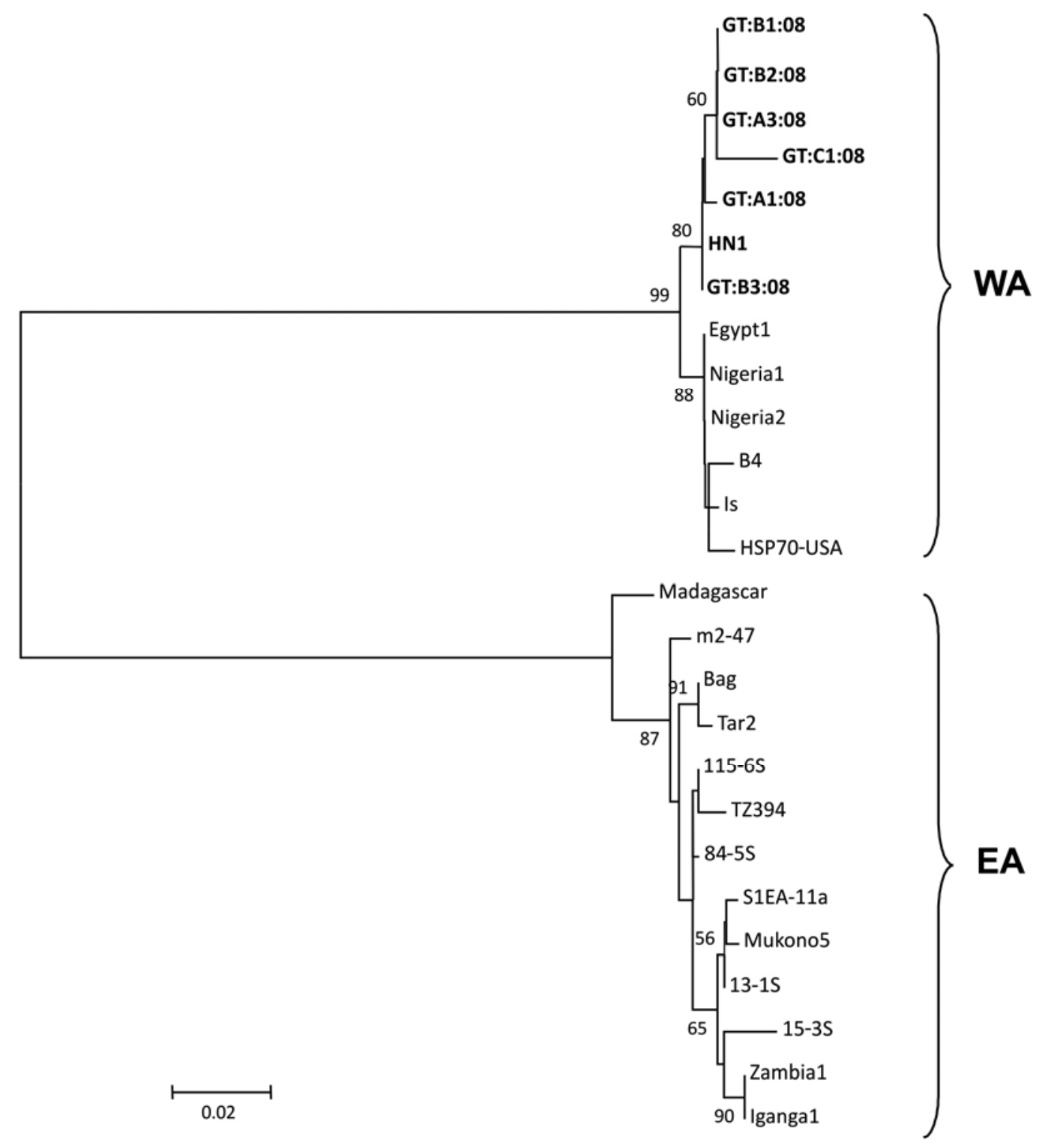

Fig. 3. Phylogenetic analysis of the Sweet potato chlorotic stunt virus (SPCSV) partial HSP70h gene sequences (430 nucleotides). Clusters containing virus isolates belonging to the two strains of SPCSV (EA and WA) are shown. New isolates characterized belonging to strain WA are in bold. Bar indicates Kimura units. Bootstrap values are for 1,000 replicates. 
ited to the NCBI nucleotide sequence database (accession number FN995425).

All plants were tested by PCR using primers designed to previously characterized sequences of SPPV-A, SPPV-B, and SPSMV-1. The plant GLP5 from the Galapagos Islands and all plants from Honduras were positive when tested with primers for SPPV-B, whereas SPPV-A and SPSMV-1 were detected only in the plant GLP5 from the Galapagos Islands (Table 2). Sequencing the amplicons verified the results (data not shown). In contrast, no plant from Guatemala was positive for SPPV-A, SPPV-B, or SPSMV-1.

\section{Discussion}

Sweetpotato is vegetatively propagated, which enhances accumulation of viruses in the crop unless healthy planting materials are used. The large taxonomic diversity of over 30 viruses known to infect sweetpotato (5) makes virus indexing laborious and, still, renders it liable to the risk of failure to detect unknown or uncharacterized viruses. In this study, the usefulness of SRDS was demonstrated for simultaneous detection of three RNA viruses (SPCSV-WA, SPFMV-RC, and SPVC) and two DNA viruses (SPLCGV and SPPV-B) in sweetpotato grown in Honduras, Guatemala, or both. Some plants were co-infected with two to three viruses. One plant from Honduras was symptomlessly infected with SPPV-B but otherwise all infected plants developed foliar symptoms of varying severity. When symptoms were severe, SPCSVWA was always present. Purpling of leaves is also characteristic of SPCSV-infected sweetpotato plants and was observed in many plants infected with SPCSV-WA also in this study. SPCSV synergizes with many unrelated viruses in co-infected plants, which can greatly enhance symptom severity $(15,38)$.

SPCSV, SPFMV, and SPLCV have been detected in sweetpotato grown in Costa Rica but the virus isolates and strains have not been characterized at sequence level (41), which hampers their comparison with the viruses detected in our study. Although the number of samples that were viable and could be tested was limited in our study, the tuberous roots originated in several places in three countries (Honduras, Guatemala, and the Galapagos Islands of Ecuador) at the heart of the primary and secondary centers of sweetpotato domestication $(4,46)$. Hence, the results indicate that the local sweetpotato crops are exposed to several viral pathogens that may originate in the region or have been introduced in infected sweetpotato germplasm. The extent of multiple virus infection involving SPCSV and the greatly diminished size of many tubers on sale in markets suggests that virus infection should be a cause for concern for sweetpotato production. The comprehensive analysis of viruses with SRDS, a method likely to detect all types of viruses infecting sweetpotato, now provides a possibility to target further study specifically to those five viruses that were found.

SRDS also was advantageous as an approach for virus detection because no antibodies are available commercially to any sweetpotato virus detected in this study. For the three RNA viruses detected, antibodies are only available from research institutes and then only in limited amounts. PCR-based detection of the five viruses is possible but this requires virus-specific primers and, above all, advance knowledge about which viruses are likely to be infecting the samples, so that the correct primers can be selected or designed for use. In contrast, SRDS can be applied without any advance knowledge about the viruses present.

Most small-RNA reads in our study and the previous study (18) were $22 \mathrm{nt}$ long, indicating that double-stranded RNA-specific cellular RNase enzyme Dicer-like 2 (22) is most active in the virus-infected sweetpotato plants. MAQ was able to assemble and recover large portions of the viral genomes in the samples based on the 21- to 24-nt-long reads. The DNA-A genome of the $B e$ gomovirus SPLCGV was almost fully recovered (98\%); therefore, no additional tests seemed necessary to verify the results. However, because detection of Begomovirus spp. by SRDS had not been reported previously in naturally infected plants, a portion of DNAA of SPLCGV was amplified by PCR and sequenced for verification. Accumulation of siRNA has been analyzed by SRDS in to- mato plants (Solanum lycopersicum L.) inoculated with Tomato yellow leaf curl China virus (genus Begomovirus) and its associated $\beta$-satellite, and the highest coverage of certain genomic regions by small-RNA reads was 50 and $79 \%$, respectively (44). In our study, coverage of the genome sequence of Badnavirus SPPVB with small-RNA reads was also very high $(81 \%)$. The much lower coverage $(50 \%)$ of the SPPV-A genome sequence used as a reference in MAQ provided direct evidence that the samples contained SPPV-B rather than SPVV-A, which was confirmed by PCR analysis of samples from the individual plants. The plant from the Galapagos Islands not included in SRDS was tested by PCR and found to be infected with SPVV-A, SPPV-B, and also SPSMV-1. These viruses have been detected by SRDS in sweetpotato Huachano in Peru (18).

Small-RNA reads covered $84 \%$ of the partial RNA1 sequence of SPCSV-WA used as a reference. The corresponding region of the SPCSV isolates in plants HN1 and GT-A1was sequenced and found to lack the $p 22$ gene, as reported for all SPCSV isolates characterized from South America (6). The position and size of the segment of RNA1 missing from the isolates in plants HN1 and GTA1 was identical to that in previously characterized SPCSV isolates (8), as compared with isolate Ug of SPCSV-EA carrying the p22 gene (20). Only some isolates of SPCSV-EA studied from East Africa contain the $p 22$ gene (8), which encodes an efficient RNAsilencing suppressor (19), suggesting that p22 was acquired by local East African virus isolates relatively recently from an unknown source $(6,8)$.

MAQ-based siRNA assemblies covered 47 and $31 \%$ of the reference genomes of SPFMV-RC and SPVC, respectively. These results are in striking contrast with those of Kreuze et al. (18), who could reach an average sequencing depth of $470 \times$ for the whole genome of SPFMV. The reason for this difference is obvious because Kreuze and co-workers analyzed a plant co-infected with SPCSV and SPFMV, which results in synergism and 600- to 1,000fold enhancement of the titers of SPFMV; the titers of SPCSV may decline $(8,15,26)$. In our study, the sweetpotato plants infected with SPFMV or SPVC were not co-infected with SPCSV and, hence, the titers of SPFMV and SPVC as well as the amounts siRNA derived from their genomes would also be expected to be much lower.

For SRDS, pooling RNA samples from a number of plants is necessary to reduce the cost of analysis per sample. Therefore, after SDRS results are obtained, the original samples need to be retested by PCR to detect the virus-positive plants. The siRNA sequence assemblies obtained with MAQ facilitate primer design significantly by including the possible sequence differences in the virus strains in the samples, as compared with the previously characterized isolates and strains. Kreuze et al. (18) suggested that, potentially, 100 to 130 samples could be analyzed simultaneously by inclusion in a single pool of total RNA $(10 \mu \mathrm{g})$ for SRDS, provided that approximately 4 million small-RNA reads are obtained, as in their study. Our independent study shows that 4 million small-RNA reads can be readily obtained by SRDS using $10 \mu \mathrm{g}$ of the total RNA from sweetpotato leaves. The yields of small-RNA reads from many other plant species are similar (unpublished data). Taken together, the results suggest that SRDS is a widely applicable and useful method for virus detection in crops infected with a wide range of unrelated viruses and in plants about which there is little prior knowledge of the virus infections present.

\section{Acknowledgments}

We thank the Academy of Finland (grant 1134335) for financial support and I. Weinheimer (Department of Agricultural Sciences, University of Helsinki) for the primers to SPPV-A, SPPV-B, and SPSMV-1.

\section{Literature Cited}

1. Alicai, T., Fenby, N. S., Gibson, R. W., Adipala, E., Vetten, H. J., and Foster, G. D. 1999. Occurrence of two serotypes of sweet potato chlorotic stunt virus in East Africa and their associated differences in coat protein and HSP70 homologue gene sequences. Plant Pathol. 48:718-726.

2. Allen, G. C., Flores-Vergara, M. A., Krasynanski, S., Kumar, S., and 
Thompson, W. F. 2006. A modified protocol for rapid DNA isolation from plant tissues using cetyltrimethylammonium bromide. Nat. Protocols 1:2320-2325.

3. Aritua, V., Barg, E., Adipala, E., Gibson, R. W., and Vetten, J. H. 2008. Further evidence for limited genetic diversity among East African isolates of Sweet potato chlorotic stunt virus. J. Phytopathol. 156:181-189.

4. Austin, D. F. 1988. The taxonomy, evolution and genetic diversity of sweetpotatoes and related wild species. Pages 91-98 in: Exploration, Maintenance and Utilization of Sweet Potato Genetic Resources. P. Gregory, ed. International Potato Center, Lima, Peru.

5. Clark, C. A., Davis, J. A., Abad, J. A., Cuellar, W. J., Fuentes, S., Kreuze, J. F., Gibson, R. W., Mukasa, S. B., Tugume, A. K., Tairo, F., and Valkonen, J. P. T. 2012. Sweetpotato viruses: 15 years of progress on understanding and managing complex diseases. Plant Dis. 96:168-185.

6. Cuellar, W. J., Cruzado, R. K., Fuentes S., Untiveros, M., Soto, M., and Kreuze, J. F. 2011. Sequence characterization of a Peruvian isolate of Sweet potato chlorotic stunt virus: Further variability and a model for $p 22$ acquisition. Virus Res. 157:111-115.

7. Cuellar, W. J., Kreuze, J. F., Rajamäki, M. L., Untiveros, M., Crusado, K. R., and Valkonen, J. P. T. 2009. Elimination of antiviral defense by viral RNase III. Proc. Natl. Acad. Sci. USA 106:10354-10358.

8. Cuellar, W. J., Tairo, F., Kreuze, J. F., and Valkonen, J. P. T. 2008. Analysis of gene content in sweet potato chlorotic stunt virus RNA1 reveals the presence of the p22 RNA silencing suppressor in only a few isolates: Implications for viral evolution and synergism. J. Gen. Virol. 89:573-582.

9. Gibb, K. S., and Padovan, A. C. 1993. Detection of sweet potato feathery mottle in sweet potato grown in Northern Australia using an efficient and simple assay. Int. J. Pest Manage.t 39:223-228.

10. Gibbs, A., and Mackenzie, A. 1997. A primer pair for amplifying part of the genome of all potyvirids by RT-PCR. J. Virol. Methods 63:9-16.

11. Gibson, R. W., Mpembe, I., Alicai, T., Carey, E. E., Mwanga, R. O. M., Seal, S. E., and Vetten, H. J. 1998. Symptoms, aetiology and serological analysis of sweet potato virus disease in Uganda. Plant Pathol. 47:95-102.

12. Haible, D., Kober, S., and Jeske H. 2006. Rolling circle amplification revolutionizes diagnosis and genomics of geminiviruses. J. Virol. Methods 135:9-16.

13. IsHak, J. A., Kreuze, J. F., Johansson, A., Mukasa, S. B., Tairo, F., Abo ElAbbas, F. M., and Valkonen, J. P. T. 2003. Some molecular characteristics of three viruses from SPVD-affected sweetpotato plants in Egypt. Arch. Virol. 148:2449-2460.

14. Karyeija, R. F., Gibson, R. W., and Valkonen, J. P. T. 1998. The significance of sweetpotato feathery mottle virus in subsistence sweetpotato production in Africa. Plant Dis. 82:4-15.

15. Karyeija, R. F., Kreuze, J. F., Gibson, R. W., and Valkonen, J. P. T. 2000. Synergistic interactions of a potyvirus and a phloem-limited crinivirus in sweetpotato cultivars. Virology 269:26-36.

16. Kimura, M. 1980. A simple method for estimating evolutionary rates of base substitutions through comparative studies of nucleotide sequences. J. Mol. Evol. 16:111-120

17. Kreuze, J. F., Karyeija, R. F., Gibson, R. W., and Valkonen, J. P. T. 2000. Comparisons of coat protein gene sequences show that East African isolates of Sweet potato feathery mottle virus from a genetically distinct group. Arch. Virol. 145:567-574.

18. Kreuze, J. F., Perez, A., Untiveros, M., Quispe, D., Fuentes, S., Barker, I., and Simon, R. 2009. Complete viral genome sequence and discovery of novel viruses by deep sequencing of small RNAs: A generic method for diagnosis, discovery and sequencing of viruses. Virology 388:1-7.

19. Kreuze, J. F., Savenkov, E. I., Cuellar, W., Li, X., and Valkonen, J. P. T. 2005. Viral class 1 RNase III involved in suppression of RNA silencing. J. Virol. 79:7227-7238.

20. Kreuze, J. F., Savenkov, E. I., and Valkonen, J. P. T. 2002. Complete genome sequence and analyses of the subgenomic RNAs of Sweet potato chlorotic stunt virus reveal new features for the genus Crinivirus. J. Virol. 76:9260-9270.

21. Li, H., Ruan, J., and Durbin, R. 2008. Mapping short DNA sequencing reads and calling variants using mapping quality scores. Genome Res. 18:1851-1858

22. Llave, C. 2010. Virus-derived small interfering RNAs at the core of plantvirus interactions. Trends Plant Sci. 15:701-707.

23. Loebenstein, G., and Thottappilly, G., eds. 2009. The Sweetpotato. Springer Sciences Business Media BV, Dordrecht, The Netherlands.

24. Mbanzibwa, D. R., Tairo, F., Wandu, G., Kullaya, A., and Valkonen, J. P. T. 2011. First report of Sweetpotato symptomless mastrevirus 1 and Sweetpotato badnavirus A in sweetpotatoes in Tanzania. Plant Dis. 95:225.
25. Moyer, J. W., and Salazar, L. F. 1989. Viruses and viruslike diseases of sweet potato. Plant Dis. 73:451-455.

26. Mukasa, S. B., Rubaihayo, P. R., and Valkonen, J. P. T. 2006. Interactions between a crinivirus, an ipomovirus and a potyvirus in co-infected sweetpotato plants. Plant Pathol. 55:458-467.

27. Mukasa, S. B., Tairo, F., Kullaya, A., Rubaihayo, P. R., and Valkonen, J. P. T. 2003. Coat protein sequence analysis reveals occurrence of new strains of Sweet potato feathery mottle virus in Uganda and Tanzania. Virus Genes 27:49-56.

28. Pallett, D. W., Ho, T., Cooper, I., and Wang, H. 2010. Detection of Cereal yellow dwarf virus using small interfering RNAs and enhanced infection rate with Cocksfoot streak virus in wild cocksfoot grass (Dactylis glomerata). J. Virol. Methods 168:223-227.

29. Pantaleo, V., Saldarelli P., Miozzi, L., Giampetruzzi, A., Gisel, A., Moxon, S., Dalmay, T., Bisztray, G., and Burgyan, J. 2010. Deep sequencing analysis of viral short RNAs from an infected Pinot Noir grapevine. Virology 408:49-56.

30. Paprotka, T., Boiteux, L. S., Fonseca, M. E. N., Resende, R. O., Jeske, H Faria, J. C., and Ribeiro, S. G. 2010. Genomic diversity of sweet potato geminiviruses in a Brazilian germplasm bank. Virus Res. 149:224-233.

31. Parrella, G., De Stradis, A., and Giorgini, M. 2006. Sweet potato feathery mottle virus is the casual agent of sweetpotato virus disease in Italy. Plant Pathol. 55:818.

32. Rännäli, M., Czekaj, V., Jones, R. A. C., Fletcher, J. D., Mu, L., Davis, R., and Valkonen, J. P. T. 2009. Molecular characterization of Sweet potato feathery mottle virus (SPFMV) isolates from Easter Island, French Polynesia, New Zealand and southern Africa. Plant Dis. 93:933-939.

33. Ryu, K. H., Kim, S. J., and Park, W. M. 1998. Nucleotide sequence analysis of the coat protein genes of two Korean isolates of sweet potato feathery mottle potyvirus. Arch. Virol. 143:557-562.

34. Tairo, F., Jones, R. A. C., and Valkonen, J. P. T. 2006. Potyvirus complexes in sweet potato: Occurrence in Australia, serological and molecular resolution, and analysis of the Sweet potato virus 2 (SPV2) component. Plant Dis. 90:1120-1128.

35. Tairo, F., Mukasa, S. B., Jones, R. A. C., Kullaya, A., Rubaihayo, P. R., and Valkonen, J. P. T. 2005. Unravelling the genetic diversity of the three main viruses involved in sweet potato virus disease (SPVD), and its practical implications. Mol. Plant Pathol. 6:199-211.

36. Tamura, K., Dudley, J., Nei, M., and Kumar, S. 2007. MEGA4: Molecular Evolutionary Genetics Analysis (MEGA) software version 4.0. Mol. Biol. Evol. 24:1596-1599.

37. Untiveros, M., Fuentes, S., and Kreuze, J. F. 2008. Molecular variability of Sweet potato feathery mottle virus and other potyviruses infecting sweet potato in Peru. Arch. Virol. 153:473-483.

38. Untiveros, M., Fuentes, S., and Salazar, L. F. 2007. Synergistic interaction of Sweet potato chlorotic stunt virus (Crinivirus) with carla-, cucumo-, ipomo-, and potyviruses infecting sweet potato. Plant Dis. 91:669-676.

39. Untiveros, M., Quispe, D., and Kreuze, J. F. 2010. Analysis of complete genomic sequences of isolates of the Sweet potato feathery mottle virus strains $\mathrm{C}$ and EA: Molecular evidence for two distinct potyvirus species and two P1 protein domains. Arch. Virol. 155:2059-2063.

40. Valverde, R., Lozano, G., and Navas-Castillo, J. 2004. First report of Sweet potato chlorotic stunt virus and Sweet potato feathery mottle virus infecting sweet potato in Spain. Plant Dis. 88:428.

41. Valverde, R., and Moreira, M. A. 2004. Identificacion de virus en el cultivo de camote (Ipomoea batatas) en Costa Rica. Agron. Mesoam. 15:1-7.

42. Woolfe, J. A. 1992. Sweet Potato, an Untapped Food Resource. Cambridge University Press, Cambridge.

43. Wyatt, S. D., and Brown, J. K. 1996. Detection of subgroup III geminivirus isolates in leaf extracts by degenerate primers and polymerase chain reaction. Phytopathology 86:1288-1293.

44. Yang, X., Wang, Y., Guo, W., Xie, Y., Xie, Q., Fan, L., and Zhou, X. 2011. Characterization of small interfering RNAs derived from the geminivirus/betasatellite complex using deep sequencing. PLoS One 6:e16928. Online publication. doi:10.1371/journal.pone.0016928

45. Zerbino, D. R., and Birney, E. 2008. Velvet: Algorithms for de novo short read assembly using de Bruijn graphs. Genome Res. 18:821-829.

46. Zhang, D., Rossel, G., Kriegner, A., and Hijmans, R. 2004. AFLP assessment of diversity in sweetpotato from Latin America and the pacific region: its implications of the dispersal of the crop. Genet. Resour. Crop Evol. 51:115-120.

47. Zhang, Y., Singh, K., Kaur, R., and Qiu, W. 2011. Association of a novel DNA virus with the grapevine vein-clearing and vine decline syndrome. Phytopathology 101:1081-1090. 